\title{
Differentiation Potential and GFP Labeling of Sheep Bone Marrow-Derived Mesenchymal Stem Cells
}

\author{
Marta Czernik, ${ }^{1 *}$ Antonella Fidanza, ${ }^{1}$ Martina Sardi, ${ }^{1}$ Cesare Galli, ${ }^{2,3,4}$ Dario Brunetti, ${ }^{2}$ \\ Daniela Malatesta, ${ }^{1}$ Leonardo Della Salda, ${ }^{1}$ Kazutsugu Matsukawa, ${ }^{5}$ Grazyna E. Ptak, ${ }^{1}$ and \\ Pasqualino Loi ${ }^{1 *}$ \\ ${ }^{1}$ Department of Comparative Biomedical Science, University of Teramo, 64100 Teramo, Italy \\ ${ }^{2}$ Laboratory of Reproductive Technologies, Avantea Srl, 26100, Cremona, Italy \\ ${ }^{3}$ Department of Veterinary Medical Sciences, University di Bologna, Ozzano Emilia, Italy \\ ${ }^{4}$ Fondazione Avantea, 26100 Cremona, Italy \\ ${ }^{5}$ Laboratory of Animal Science, College of Agriculture, Kochi University, Nankoku, Japan
}

\begin{abstract}
Mesenchymal stem cells (MSCs) are an important cell population in the bone marrow microenvironment. MSCs have the capacity to differentiate in vitro into several mesenchymal tissues including bone, cartilage, fat, tendon, muscle, and marrow stroma. This study was designed to isolate, expand, and characterize the differentiation ability of sheep bone marrow-derived MSCs and to demonstrate the possibility to permanently express a reporter gene. Bone marrow was collected from the iliac crest and mononuclear cells were separated by density gradient centrifugation. Sheep MSCs cell lines were stable characterized as CD44+ and CD34- and then transfected with a green fluorescent protein (GFP) reporter gene. The GFP expression was maintained in about half (46.6\%) of cloned blastocysts produced by nuclear transfer of GFP+ sheep MSCs, suggesting the possibility to establish multipotent embryonic cells' lines carrying the fluorescent tag for comparative studies on the differentiation capacity of adult stem cells (MSCs) versus embryonic stem cells. We found that sheep MSCs under appropriate culture conditions could be induced to differentiate into adipocytes, chondrocytes, and osteoblast lineages. Our results confirm the plasticity of sheep MSCs and establish the foundation for the development of a pre-clinical sheep model to test the efficiency and safety of cell replacement therapy. J. Cell. Biochem. 114: 134-143, 2013. ๑ 2012 Wiley Periodicals, Inc.
\end{abstract}

KEY WORDS: ADIPOCYTES; CELL DIFFERENTIATION; CHONDROCYTES; GREEN FLUORESCENT PROTEIN (GFP); OSTEOBLASTS; SHEEP MESENCHYMAL STEM CELLS (MSCS)

$\mathrm{S}$ tem and multipotent cells are not exclusive to the embryonic and early post-natal period of ontogenesis but are also present during the entire life of an organism [Howlett et al., 1986; Caplan, 1991, 2007; Pittenger, 2008]. Many adult tissues contain a small population of stem cells that have a capacity for renewal after trauma, disease, or aging. Over the last decade, a large number of studies have indicated that adult stem cells might exhibit a greater degree of plasticity than their fate choice. For example, adult bone marrow contains mesenchymal stem cells (MSCs) that are not only capable of self-renewal but also to differentiated into many mesenchymal-derived phenotypes, including bone, cartilage, fat, tendon, muscle, and marrow stroma [Friedenstein et al., 1987; Kuznetsov et al., 1997; Procop, 1997]. This property has made MSCs potential candidates for cell replacement therapy for the treatment of many human diseases affecting the cardiovascular, pulmonary, osteoarticular cartilage, and nervous tissue [Pittenger et al., 2000; Toma et al., 2002]. There are already several examples of using bone marrow for the treatment of segmental bone defects [Quarto et al.,

Grant sponsor: The European Research Council; Grant number: FP7/2007-2013; Grant sponsor: Programme IDEAS; Grant number: 210103; Grant sponsor: EU FP6 (Xenome); Grant number: LSHB-CT-2006-037377; Grant sponsor: EU FP7 (Plurisys); Grant number: 223485; Grant sponsor: Regione Lombardia (Superpig Project) in CG Laboratory; Grant sponsor: FP7 EU “NextGen,” PRIN 2009 MIUR, and Tercas.

D. Brunetti's present address is Division of Molecular Neurogenetics, IRCCS Foundation Neurological Institute, “C.Besta” Via Temolo 4, 20126 Milano, Italy

*Correspondence to: M. Czernik or P. Loi, Department of Comparative Biomedical Science, University of Teramo, Piazza Aldo Morro 45, 64100 Teramo, Italy. E-mail: mczernik@unite.it; ploi@unite.it

Manuscript Received: 29 June 2012; Manuscript Accepted: 26 July 2012

Accepted manuscript online in Wiley Online Library (wileyonlinelibrary.com): 6 August 2012

DOI 10.1002/jcb.24310 • (c) 2012 Wiley Periodicals, Inc.

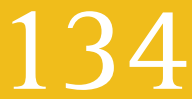


2001] and craniotomy [Krebsbach et al., 1998]. Similar approaches have also been described for the repair of lesions in tendon and cartilage [Ponticiello et al., 2000].

Despite such progress, however, many publications have also brought about some scepticism regarding the real regeneration potential of adult stem cells [Terada et al., 2002; Ying et al., 2002]. Moreover, the long-term safety of grafted MSCs is still waiting definitive answers.

The biology and properties of MSCs from bone marrow are well characterized in mice and human [Lublin et al., 1989; Pittenger et al., 1999, 2002], but also in some animals like cat [Martin et al., 2002], dog [Kadiyala et al., 1997], rabbit [Howlett et al., 1986], pig, and bovine [Ringe et al., 2002; Colleoni et al., 2005]. Alternatively, the characterization of sheep MSCs is still in its infancy [McCarty et al., 2009], although animals such as sheep offer unparalleled advantages compared with the mouse. Their larger size allows surgical operation, and non-invasive diagnostics almost similar to those routinely performed on humans. Moreover, the relatively long-lifespan allows follow up studies in order to ensure longterm safety of the transplanted cells [Galmozzi et al., 2006; Sell, 2006].

The aims of the study were: (1) to assess whether the differentiation plasticity of sheep bone marrow mesenchymal stem cells (MSCs) can be explored with a classic histochemical and molecular biology approach and (2) to permanently label the mesenchymal cells with a green fluorescent protein (GFP) reporter. We successfully managed to establish proper culture condition for the expansion of phenotypical and genetically stable sheep presumptive MSCs, and to successfully differentiate and characterized them into adipo/osteo and chondrocytes. Moreover, MSCs were stably transfected with a GFP reporter gene, whose expression was maintained in blastocyst stage embryos derived from nuclear transfer of GFP + sheep MSCs. These results represent the foundation for the production of a preclinical sheep model for cell transplantation therapy.

\section{MATERIALS AND METHODS}

\section{ISOLATION OF MSCs}

Bone marrow has been collected under general anesthesia (according to DPR 27/1/1992, Animal Protection Regulations of Italy DGL 116/92, with conformity with Directive 86/609/EEC) from the iliac crest from four Sarda breed ewes (6-7 years old) using a trocar connected to a 20-ml syringe filled with medium TCM 199 and sodium heparine. Mononuclear cells were isolated by a density gradient separation method. Bone marrow was diluted with PBS/ EDTA at 1:1 and separated using a 30-min centrifugation at $1,800 \mathrm{~g}$ after layering on Ficoll (Amersham Biosciences, Milan, Italy). The cells were rinsed twice with PBS and viability was determined with trypan blue staining (Sigma-Aldrich, Milan, Italy). Subsequently, the cells were cultured in Dulbecc's Modified Eagle Medium (DMEM) (Invitrogen, Milan, Italy) containing 15\% fetal bovine serum (FBS), $40 \mu \mathrm{l} / \mathrm{ml}$ gentamicine (Sigma-Aldrich), $20 \mathrm{mM} \mathrm{L-glutamine} \mathrm{(Sigma-}$ Aldrich) at a density of $2 \times 10^{6}$ cells $/ \mathrm{cm}^{2}$ in $25-\mathrm{cm}^{2}$ flasks at $37^{\circ} \mathrm{C}$, $5 \% \mathrm{CO}_{2}$ and humid ambient.
The floating cells and medium were discarded after 24 and $48 \mathrm{~h}$ and the adherent cells were expanded in flasks. Medium changes were done every 3 days. When the cells were $70-80 \%$ confluent they were detached from the surface with $0.25 \%$ TrypsineEDTA.

\section{DETECTIONS OF CD44 AND CD34 IN SHEEP MSCs}

Expression of CD44 and CD34 in sheep MSCs was demonstrated by indirect immunofluorescence. Cells were washed in PBS and fixed in $4 \%$ paraformaldehyde at room temperature for $20 \mathrm{~min}$, followed by treatment in $0.2 \%$ Triton X-100 under the same conditions. Cells were then incubated with the primary CD44 and CD34 polyclonal antibody (Santa Cruz Biotechnology Inc., Santa Cruz, CA, USA) $(1: 50,1: 25)$ at $4{ }^{\circ} \mathrm{C}$ overnight. After washing in $0.1 \% \mathrm{BSA} / 0.05 \%$ Tween 20/PBS, cells were incubated with the secondary antibodies conjugated to FITC 1:500 at room temperature for $1 \mathrm{~h}$. Propidium iodide $(0.5-1.0 \mu \mathrm{g} / \mathrm{ml})$ was used to counterstain cells. As a negative control, cells were processed in the same way but for the absence of the primary antibody. Images were captured with a fluorescence microscope (Nikon, Tokyo, Japan).

\section{ADIPOCYTES DIFFERENTIATION AND CHARACTERIZATION}

Sheep MSC were plated at a density of $2-5 \times 10^{3} / \mathrm{cm}^{2}$ and grown at $38.5^{\circ} \mathrm{C}$ in an atmosphere of 95\% air and $5 \% \mathrm{CO}_{2}$. Cells were grown to $100 \%$ confluence in the growth medium supplemented with $10 \%$ FBS. Two days post-confluence cells were incubated in adipogenesis-inducing medium (MDI + I) containing $1 \mu \mathrm{M}$ dexamethasone (Sigma-Aldrich), $0.5 \mathrm{mM}$ methyl-isobutylxanthine (Sigma-Aldrich), insulin $10 \mathrm{~g} / \mathrm{ml}$ (Sigma-Aldrich), $100 \mathrm{mM}$ indomethacin (SigmaAldrich), and 10\% FBS in DMEM (Invitrogen). The sheep MSCs were incubated in this media for $72 \mathrm{~h}$ and the media was changed to adipogenic maintenance (AM) media containing insulin $10 \mu \mathrm{g} / \mathrm{ml}$ and 10\% FBS in DMEM for $24 \mathrm{~h}$. The cells were then re-treated with MDI + I for a total of four treatments. The cultures were then maintained in AM for 1 week to up to 35 days of differentiation. Adipogenesis differentiation was demonstrated by the accumulation of neutral lipid vacuoles and Oil 0 Red staining. Adult skin fibroblasts were used as a control cultured in the same differentiation media for 35 days and then stained with Oil 0 Red. Pictures were taken under Nikon Eclipse E600 Light Microscope (Nikon) equipped with a Nikon pressure mercury arc lamp connected to Nikon Digital Camera DXM1200.

\section{OSTEOGENIC DIFFERENTIATION AND CHARACTERIZATION}

Osteogenic differentiation was induced by culturing sheep mesenchymal cells for 5 weeks in differentiation media containing the following: 10\% FBS in DMEM-low glucose supplemented with $50 \mu \mathrm{g} / \mathrm{ml}$ ascorbic acid (Sigma-Aldrich), $3 \mathrm{mM} \beta$-glycerophosphate (Sigma-Aldrich), and $10 \mathrm{nM}$ dexamethasone. The medium was refreshed every 3 days. Alizarin red and von Kossa staining visualized mineralized deposits. Control sheep MSCs and skin fibroblasts were used as a control by culturing them in the same differentiation media for 35 days and then identified by Alizarin red staining. Pictures were taken under Nikon Eclipse E600 Light Microscope (Nikon) equipped with a Nikon 
pressure mercury arc lamp connected to Nikon Digital Camera DXM1200.

\section{CHONDROBLAST DIFFERENTIATION AND CHARACTERIZATION}

The $2.5 \times 10^{5}$ third or fourth passage sheep mesenchymal cells were placed in $15 \mathrm{ml}$ polypropylene tubes and centrifuged for $10 \mathrm{~min}$ at $1,500 \mathrm{rpm}$ to develop a 3D cell pellet. The pellet was incubated for $24 \mathrm{~h}$ in $95 \%$ air and $5 \% \mathrm{CO}_{2}$ at $37^{\circ} \mathrm{C}$ in serum-free medium. At the end of starvation, the chondrogenic incubation medium was added and consisted of $10 \mathrm{~nm}$ dexamethazone (Sigma-Aldrich), $10 \mathrm{ng} / \mathrm{ml}$ TGF- $\beta$ (Sigma-Aldrich) and $50 \mathrm{mg} / \mathrm{ml}$ ITS in DMEM-HG with 10\% FBS (Invitrogen). The medium was changed every 3 days over 5 weeks. Sheep MSCs and skin fibroblasts were used as a control. Mesenchymal and fibroblast pellets were fixed in 10\% neutralbuffered formalin, embedded in paraffin wax, sectionated at $5 \mu \mathrm{m}$. Sections were stained with Alcian blue $\mathrm{pH} 2.5$ and examined by light microscopy in order to evaluate the presence of acidic proteoglycans produced by chondrocyte [Kawaguchi et al., 2006; Kadouchi et al., 2009]. Pictures were taken under Nikon Eclipse E600 Light Microscope (Nikon) equipped with a Nikon pressure mercury arc lamp connected to Nikon Digital Camera DXM1200.

\section{EXPRESSION ANALYSIS}

Expression analysis have been performed on MSCs, adipocytes, osteoblasts, chondrocytes, using fat tissue, bone and cartilage as positive control for differentiate cells and fibroblast as negative control. Fat tissue has been homogenized using a potter, while bone and cartilage have been powered in liquid nitrogen. Cells and homogenized tissue have been equally treated for RNA extraction. mRNA were extracted from each sample using Dynabeads mRNA direct kit (Invitrogen) according to the standard recommended protocol. Of total, $10 \mu \mathrm{l}$ of mRNA have been retrotranscribed with the Quantitech Reverse Transcription Kit (Qiagen, Milan, Italy), obtained cDNA have been diluted 1:3 in molecular biology grade $\mathrm{H}_{2} \mathrm{O}$. PCR reactions have been performed with the PCR Master Mix (Promega, Milan, Italy), in a final volume of $12.5 \mu \mathrm{l}$ containing $5 \mathrm{pmol}$ of each primer and $1 \mu \mathrm{l}$ of cDNA. PCR conditions are reported in Table I.

\section{KARYOTYPING ANALYSIS}

Sheep MSCs at passage 15 and 40 were cultured for $4 \mathrm{~h}$ with $0.5 \mu \mathrm{g} / \mathrm{ml}$ Colcemid (Sigma, Milan, Italy), then harvested and transferred to hypotonic solution $1: 1 \mathrm{KCl}$ :sodium citrate for $20 \mathrm{~min}$ at $37^{\circ} \mathrm{C}$. Cells were fixed in 3:1 methanol:acetic acid for $15 \mathrm{~min}$ at $4^{\circ} \mathrm{C}$ and then were span twice at $1,200 \mathrm{rpm}$ for $10 \mathrm{~min}$. MSCs were carefully resuspended in the fixative and spreading was done on microscope glass slides. Slides were stained with 4\% Giemsa for $10 \mathrm{~min}$. Pictures were taken under $100 \times$ in immersion oil Nikon Eclipse E600 Light Microscope (Nikon) equipped with a Nikon pressure mercury arc lamp connected to Nikon Digital Camera DXM1200 and chromosomes were counted.

\section{EGFP EXPRESSION VECTOR}

All restriction and modification enzymes were from Fermentas (St Leon-Rot, Germany) unless otherwise stated. The $2.989 \mathrm{~kb}$ SalI-PstI EGFP expression cassette was excised from pCXEGFP [Niwa et al., 1991] and inserted in the vector pBSMAR [Stief et al., 1989] digested with the same enzymes, creating the pBSMAR-CXEGFP vector.

Finally, to create the Neomycin (Neo R) loxable selection cassette, the XhoI-NotI fragment $(5.963 \mathrm{~kb})$ of the pBSMAR-CXEGFP construct was cloned into the pPGKneoPpoly vector (previously created in our laboratory) digested with the same restriction enzymes to obtain the pAP1 (10.912 kb, Fig. 1A of [Brunetti et al., 2008]).

\section{CELLS TRANSFECTION}

The day before transfection, sheep mesenchymal cells at passage 3 were trypsinized, counted and plated into 60- $\mathrm{mm}$ dish in order to have about $5 \times 10^{5}$ cells at $80 \%$ confluency after $24 \mathrm{~h}$; on the day of transfection cells were trypsinized, counted, resuspended in $100 \mu \mathrm{l}$ of nucleofector solution (Human MSC Nucleofector Kit; Amaxa, Cologne, Germany), mixed with $3 \mu \mathrm{g}$ plasmid pAP1 transferred into the nucleofection cuvettes and transfected with V-24 program (Nucleofector Amaxa). After nucleofection cells were plated in 60$\mathrm{mm}$ culture dishes with fresh medium; $24 \mathrm{~h}$ later cells were trypsinized and re-plated in three 150-mm culture dishes and after a further $24 \mathrm{~h}$ the drug for selection (G418: $500 \mu \mathrm{g} / \mathrm{ml}$ for 8 days) was added. Selection medium was changed every 3 days. After 8-9 days, dishes were observed under UV, colonies with high and uniform fluorescence expression were picked up using 5-mm cloning discs, transferred into 24-mm well dishes. Cells were cultured in DMEM (Invitrogen) with 10\% FBS in 5\% $\mathrm{CO}_{2}$ and 5\% $\mathrm{O}_{2}$ in humidified air at $38.5^{\circ} \mathrm{C}$.

\section{NUCLEAR TRANSFER OF GFP TRANSFECTED CELLS}

Oocyte maturation. Oocytes were matured in vitro in bicarbonatebuffered TCM-199 (Gibco, Milan, Italy) (275 m0sm) containing $2 \mathrm{mM}$ glutamine, $100 \mu \mathrm{M}$ cysteamine, $0.3 \mathrm{mM}$ sodium pyruvate, 10\% FBS (Gibco), $5 \mu \mathrm{g} / \mathrm{ml}$ follicle-stimulating hormone (FSH; IcpBIO, Auckland, New Zealand), $5 \mu \mathrm{g} / \mathrm{ml}$ luteinizing hormone (LH),

TABLE I. PCR Primers and Conditions Used in Study

\begin{tabular}{|c|c|c|c|}
\hline Gene & Primer $5^{\prime}-3^{\prime}$ & Fragment (bp) & PCR condition \\
\hline $\begin{array}{l}\mu \text {-Tubulin } \\
\text { NM_001009284.1 }\end{array}$ & $\begin{array}{l}\text { Fw CCATCCAGCGTATTCCAGAGG } \\
\text { Rv GCGTGGGACAGAAGGTAGAA }\end{array}$ & 202 & $\begin{array}{c}95^{\circ} \mathrm{C} 5^{\prime} \\
95^{\circ} \mathrm{C} 30^{\prime \prime} / 56^{\circ} \mathrm{C} 30^{\prime \prime} / 72^{\circ} \mathrm{C} 30^{\prime \prime} \text { (35 cycles) }\end{array}$ \\
\hline $\begin{array}{l}\text { FABP4 } \\
\text { NM_001114667.1 }\end{array}$ & $\begin{array}{l}\text { Fw TGGGATGTGGTCAACATTA } \\
\text { Rv CAGCACCAGCTTATCATCCA }\end{array}$ & 216 & $\begin{array}{c}95^{\circ} \mathrm{C} 5^{\prime} \\
95^{\circ} \mathrm{C} 30^{\prime \prime} / 56^{\circ} \mathrm{C} 30^{\prime \prime} / 72^{\circ} \mathrm{C} 30^{\prime \prime} \text { (30 cycles) } 72^{\circ} \mathrm{C} 5^{\prime}\end{array}$ \\
\hline $\begin{array}{l}\text { Collagen I } \\
\text { AF129287.1 }\end{array}$ & $\begin{array}{l}\text { Fw AGGGACCCAAAGGAGACAT } \\
\text { Rv GCACGGAAATTCCTGTTGAT }\end{array}$ & 198 & $\begin{array}{c}95^{\circ} \mathrm{C} 5^{\prime} \\
95^{\circ} \mathrm{C} 30^{\prime \prime} / 60^{\circ} \mathrm{C} 30^{\prime \prime} / 72^{\circ} \mathrm{C} 30^{\prime \prime} \text { (28 cycles) } 72^{\circ} \mathrm{C} 5^{\prime}\end{array}$ \\
\hline $\begin{array}{l}\text { Aggrecan } \\
\text { AF019758 }\end{array}$ & $\begin{array}{l}\text { Fw GCCATCTGCTACACAGGTGA } \\
\text { Rv AAAGGCTCCTCAGGTTCTGG }\end{array}$ & 218 & $\begin{array}{c}95^{\circ} \mathrm{C} 5^{\prime} \\
95^{\circ} \mathrm{C} 30^{\prime \prime} / 58^{\circ} \mathrm{C} 30^{\prime \prime} / 72^{\circ} \mathrm{C} 30^{\prime \prime} \text { (35 cycles) } 72^{\circ} \mathrm{C} 5^{\prime}\end{array}$ \\
\hline
\end{tabular}




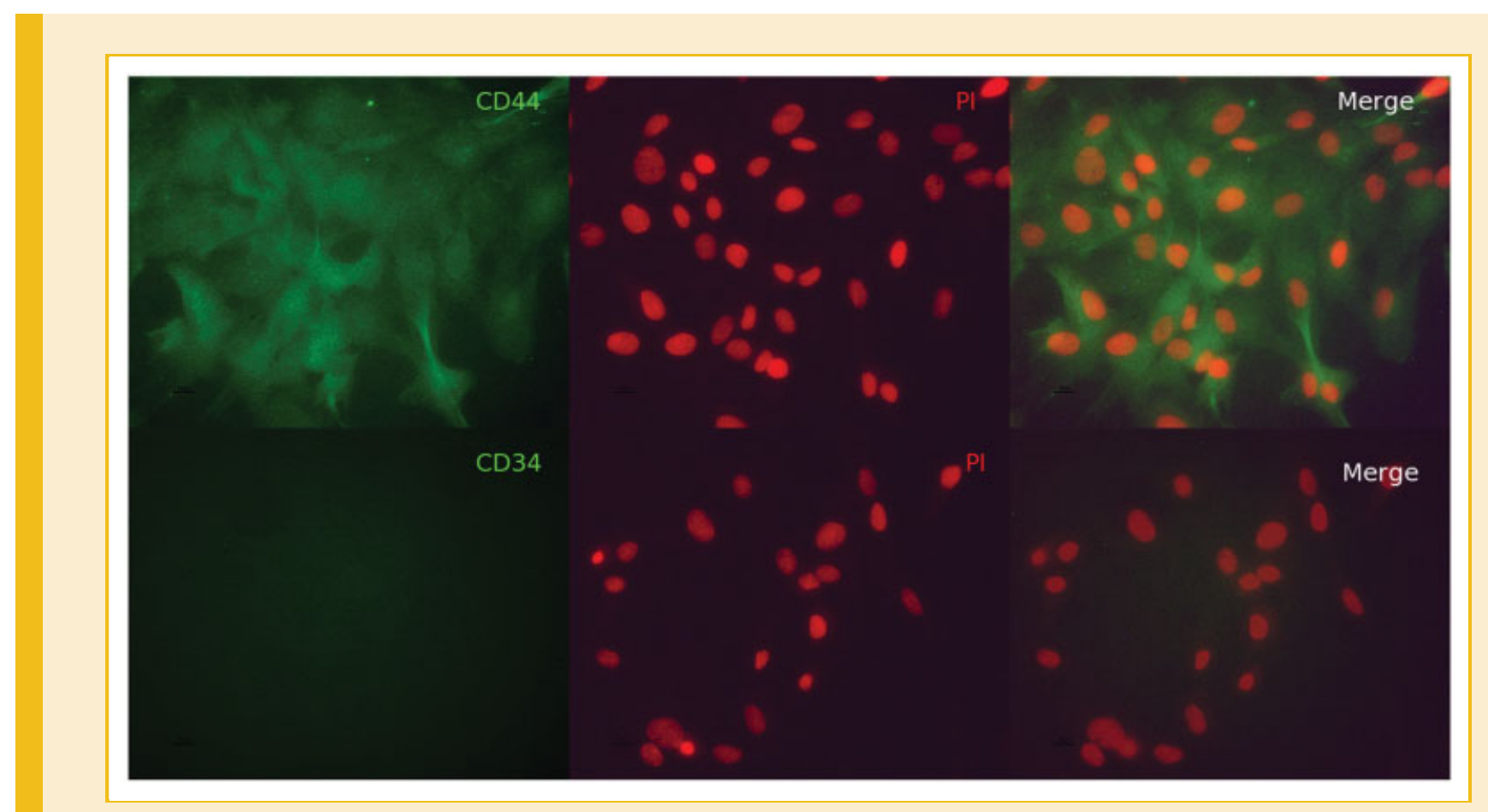

Fig. 1. Expression of CD44 and CD34 in sheep mesenchymal stem cells (MSCs). CD44 (top panel) and CD34 (bottom panel) positive cells are in green (FITC) and nuclei in red.

$1 \mu \mathrm{g} / \mathrm{ml}$ estradiol in a humidified atmosphere of $5 \% \mathrm{CO}_{2}$ in air at $39^{\circ} \mathrm{C}$ for $24 \mathrm{~h}$ [Ptak et al., 1999].

Oocyte enucleation and nuclear transfer. Oocytes were incubated in HEPES buffered 199 medium containing $4 \mathrm{mg} / \mathrm{ml}$ of BSA and $7.5 \mu \mathrm{g} / \mathrm{ml}$ of Cytochalasin B and $5 \mu \mathrm{g} / \mathrm{ml}$ of Hoechst 33342 for $10 \mathrm{~min}$ in incubator. Enucleation was carried out in HEPES buffered 199 medium plus BSA and Cytochalasin B with a Narishighe micromanipulator. Enucleate oocytes were allowed to recover from Cytochalasin B treatment enucleated oocytes were reconstructed with GFP expressing fibroblasts selected under UV. The cells were then electrofused to the recipient oocytes through a DC pulse $(1,20 \mathrm{kV} / \mathrm{cm}$ for $10 \mu \mathrm{s})$ with a BTX electroporator (ECM 830) in fusion medium (0.3 M mannitol, $01 \mathrm{M} \mathrm{MgSO}_{4}, 0.001 \mathrm{M} \mathrm{CaCl}_{2}$, and $0.4 \%$ BSA). Reconstructed oocytes were activated in HEPES buffered medium 199 containing $5 \mu \mathrm{g} / \mathrm{ml}$ ionomycin for $5 \mathrm{~min}$, then incubated in synthetic oviduct fluid (SOF) medium plus antibiotics and BSA containing $10 \mathrm{mM}$ dimethylaminopurine and $7.5 \mu \mathrm{g} / \mathrm{ml}$ Cytochalasin B for $3-5 \mathrm{~h}$.

Embryo culture. Successfully fused embryos were transferred into 20- $\mu$ l drops of SOF enriched with 1\% (v:v) Basal Medium Eagle-essential amino acids, $1 \%(\mathrm{v}: \mathrm{v})$ minimum essential mediumnonessential amino acids (Gibco), $1 \mathrm{mM}$ glutamine, and $8 \mathrm{mg} / \mathrm{ml}$ fatty acid-free BSA (SOFaaBSA). Zygote cultures were maintained in humidified atmosphere of $5 \% \mathrm{CO}_{2}, 7 \% \mathrm{O}_{2}, 88 \% \mathrm{~N}_{2}$ at $39^{\circ} \mathrm{C}$, and the medium renewed on Day 3 and Day 5 of culture [Ptak et al., 2002]. Embryonic development and GFP expression were monitored every $24 \mathrm{~h}$ until the blastocyst stage.

\section{RESULTS}

\section{ISOLATION AND EXPANSION OF SHEEP BONE MARROW-DERIVED MESENCHYMAL STEM CELLS}

MSCs primary cultures were successfully established from all fourdonor ewes. The phenotype observed was similar between the donors, with large adherent cells, normal proliferation capacity with a fibroblast-like phenotype. This phenotype was maintained during all sub-passages (40). Chromosome spreads, prepared from ovine MSCs at passages 15 and 35 revealed a normal karyotype (54XX) in all cell lines.

\section{EXPRESSION OF CELL SURFACE MARKERS}

Characterization of sheep MSCs was provided by indirectly immunofluorescence anti-CD44 and CD34. Figure 1 shown positive expression of CD44 and negative expression of CD34 markers in sheep MSCs. Furthermore, the major of antibodies reacted with human/mice MSC did not exhibit any reactivity with sheep MSCs, including CD45, CD133, and CD117 (data not shown).

\section{DIFFERENTIATION INTO ADIPOCYTIC LINEAGE}

One prominent characteristic of cell differentiation into adipocytes in the tissue culture was the observation of intracellular fat drops by phase-contrast light microscopy, which were chemically stained with Oil 0 Red (Fig. 2). As early as 1 week later, lipid drops were detectable and accumulation thereafter increased along with the inductive period up to 35 days. Multiple induction treatments resulted in many of the cells committed to the adipocyte lineage, and the lipid vacuoles continued to develop over time, coalesced, and 


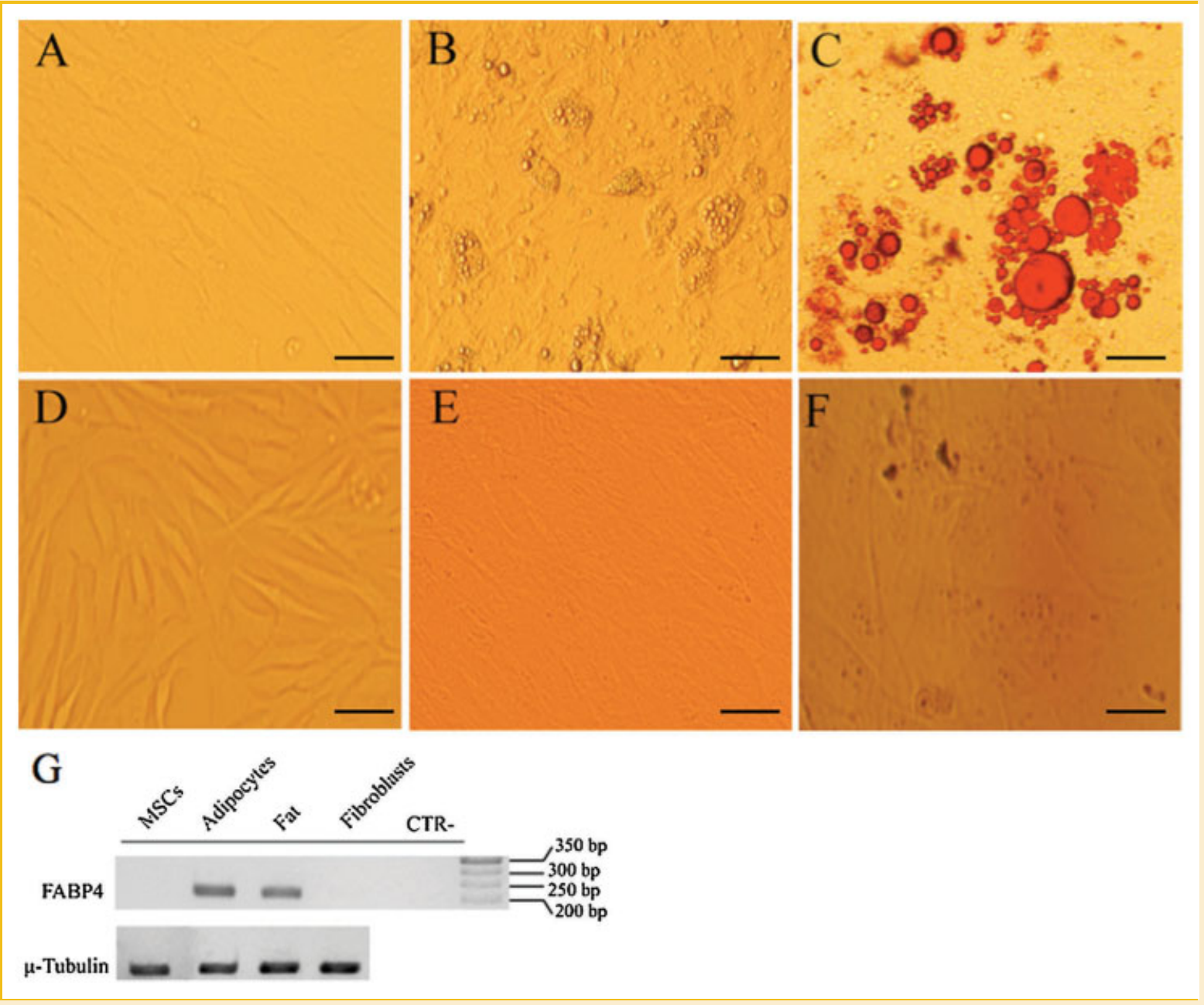

Fig. 2. Sheep MSCs differentiated into adipocytes. A-C: sheep MSCs, D-F: adult skin fibroblasts; A and D: cells before differentiation; B and E: cells after 5 weeks in differentiation media; $C$ and F: vacuoles stained with Oil 0 Red; G: expression of FABP4 and $\mu$-tubulin in MSCs before and after differentiation into adipocytes. Fat tissue and adult fibroblast have been used as control, Scale bar $=100 \mu \mathrm{m}$.

eventually filled the cell. These results have not been observed previously in control MSCs and in cultured adult skin fibroblast.

PCR analysis of expression of FABP4 (marker of adipogenesis) showed high expression in cells differentiated into adipocytes and adult fat tissue. Although FABP4 was not expressed by control samples (MSCs before induction and adult fibroblasts).

\section{DIFFERENTIATION INTO OSTEOBLASTIC LINEAGE}

Osteoblast-like cells lost their spindle-shaped structure and became rectangular growing on top of each other. Calcium accumulation was evident after 10 days and increased over 35 days of culture and mineralized cells were found using von Kossa and Alizarin red staining (Fig. 3). In contrast, cultures of control MSCs and normal skin fibroblast did not undergo any such differentiation when cultured as long as 5 weeks.

To further confirm the osteogenic differentiation, the expression of collagen $\alpha 1$ was analyzed by PCR before and after induction. Bone and fibroblasts were used as positive and negative control (respectively). Osteogenic-differentiated MSCs and bone tissue showed high level of collagen $\alpha 1$. In contrast, any positive signal was observed in control groups (MSCs before differentiation and fibroblast).

\section{DIFFERENTIATION INTO CHONDROGENIC LINEAGE}

To promote chondrogenic differentiation, sheep MSCs have been centrifuged to form a pelleted micromass. The cell pellets developed a multilayered matrix-rich morphology and histologically showed an increased proteoglycan-rich extracellular matrix during culture (Fig. 4). Any morphological or positive staining has been observed in control MSCs and in fibroblast culture. To further confirm the chondrogenic differentiation, the expression of aggrecan was analyzed by PCR before and after induction. Cartilage and fibroblasts were used as positive and negative control (respectively). MSCs differentiated into chondrocytes and cartilage showed high level of aggrecan. In contrast, any positive signal was observed in control cells (MSCs before differentiation and fibroblasts). 


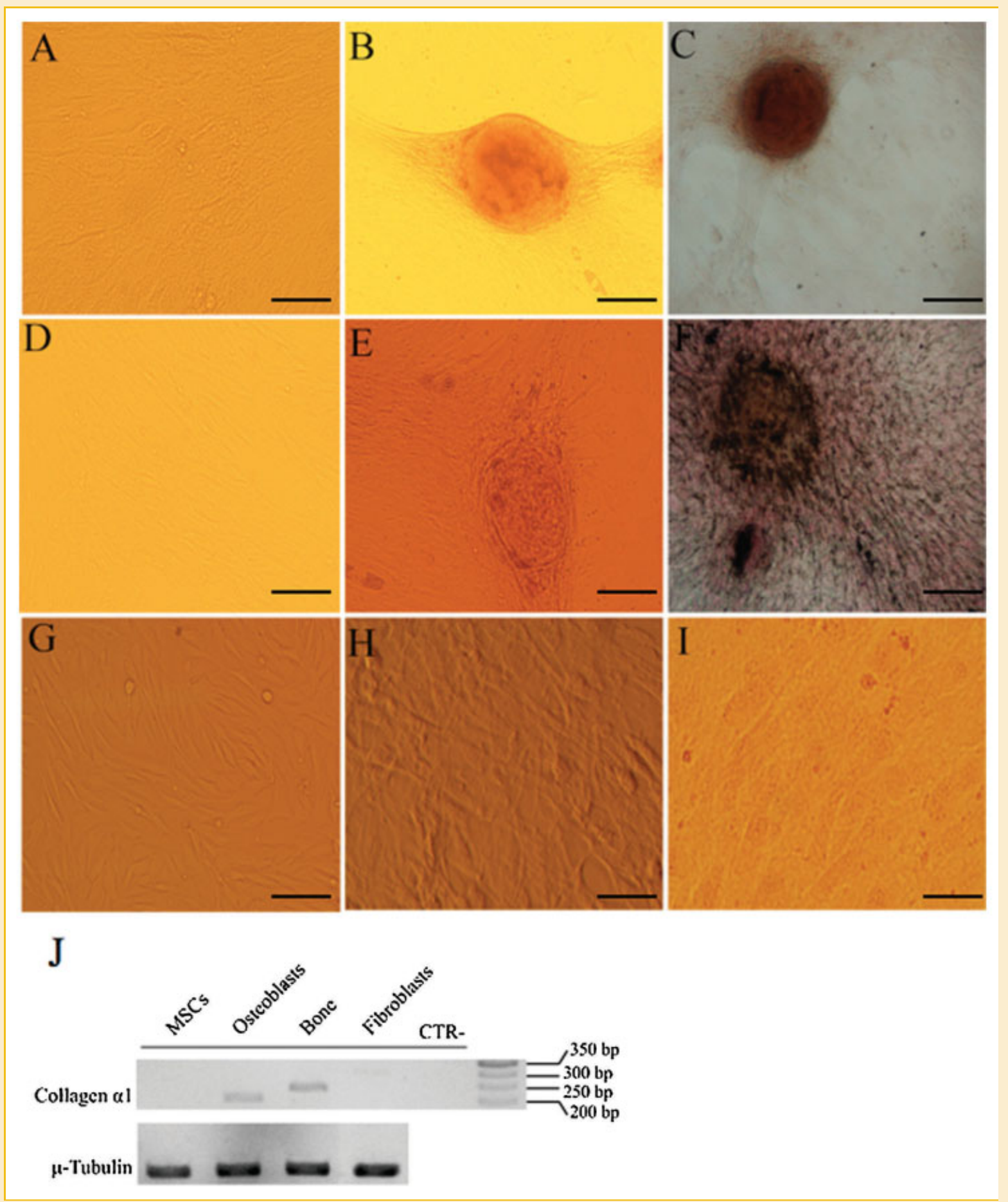

Fig. 3. Sheep MSCs differentiated into osteoblasts. A-F: sheep MSCs; G-I: sheep adult skin fibroblasts; $A, D$, and G: cells before differentiation; B, E, and H: cells after 5 weeks with differentiation media; C and I: cells stained with Alizarin red; F: cells stained with Van Kossa; J: expression of collagen $\alpha 1$ and $\mu$-tubulin in MSCs before and after differentiation into osteoblasts. Bone and fibroblast have been used as control. Scale bar $=100 \mu \mathrm{m}$.

\section{NUCLEAR TRANSFER OF GFP TRANSFECTED CELLS}

All the four cell lines were successfully transfected with the GFP plasmid, and expressed an intense green fluorescence under UV (Fig. 5). GFP positive cells have been used for SCNT. From a total of
63 embryos reconstructed with GFP expressing MSC, 15 (23) developed to blastocyst stage, and seven of those (6.6\%) uniformly expressed the transgene (Fig. 6), whereas a mosaic expression was present in three blastocyst, the other ones did not express GFP. 


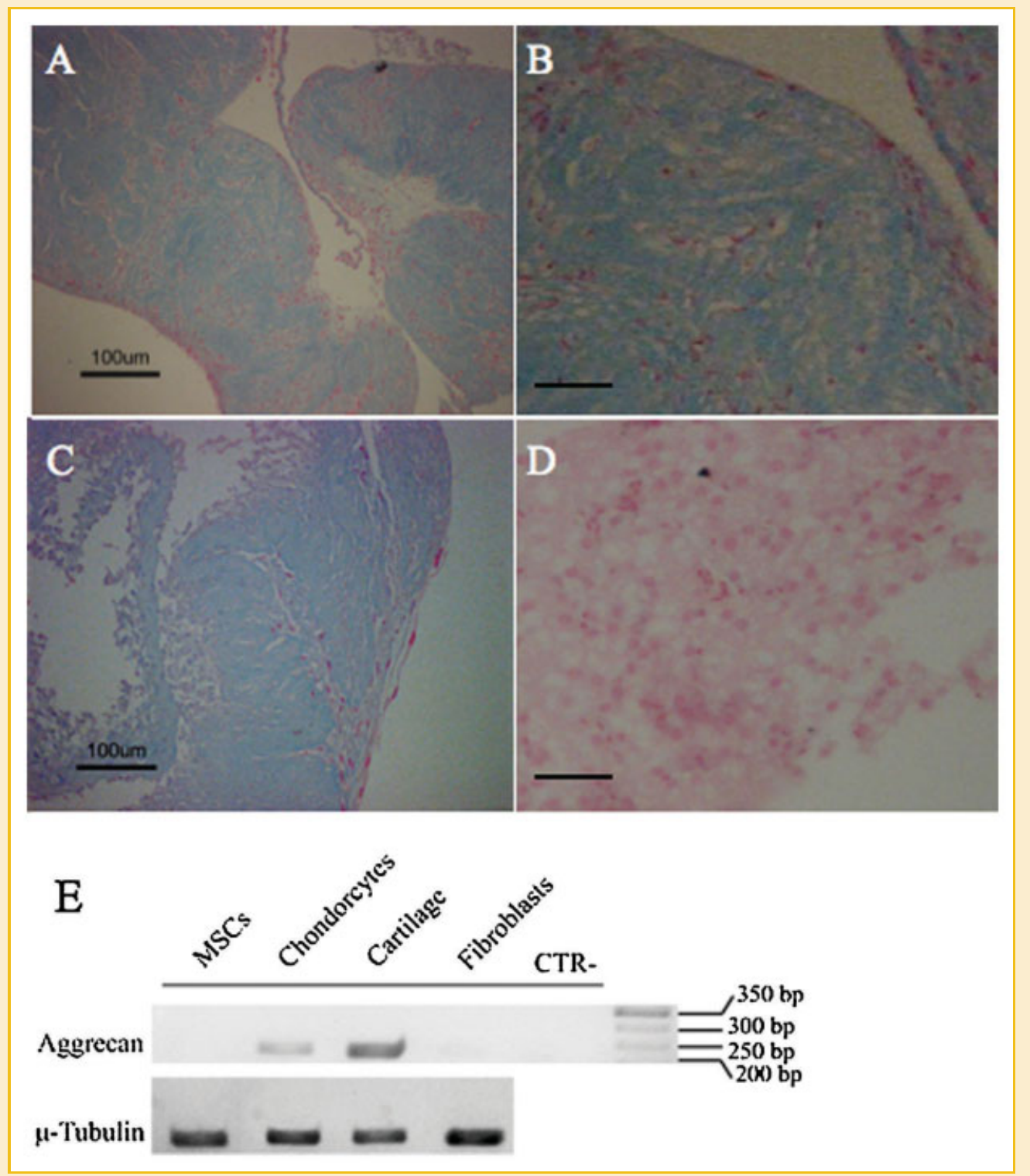

Fig. 4. Sheep MSCs differentiated into chondrocytes A and B: MSCs; C and D: sheep adult skin fibroblasts; A-D: sections stained with Alcian blue; $A$ and C-40 $;$; and D-100 ; E: expression of aggrecan and $\mu$-tubulin in MSCs before and after differentiation into chondrocytes. Cartilage and fibroblast have been used as control. Scale bar $=100 \mu \mathrm{m}$.

\section{DISCUSSION}

Currently, there is great interest in using sheep MSCs as therapeutic agents to treat many types of diseases, including osteogenesis imperfecta, spinal cord injury, stroke and myocardial infarction, owning to their remarkable ability to differentiate into many lineages [Johnson et al., 1986; Bianco and Robey, 2001; Phinney and Prockop, 2007; Abdallah and Kassem, 2008]. As a result, a plethora of scientific contribution regularly appears in the highest ranked scientific journals and adult stem cells research is rapidly being translated into clinical practice.

It is somehow surprising, however, that encouraging reports on major translational studies of MSCs, such as the successful treatment of myocardial infarction [Quevedo et al., 2009], are often followed by others carrying warning messages on the negative side effects arising from uncontrolled differentiation of MSCs, for example, fibrotic evolution of MSCs engrafted in the liver [Baertschiger et al., 2009]. Even more unexpected are the controversies regarding the actual mechanism underlying MSCs engraftment and proliferation. Is it a bona fide transdifferentiation, or can the positive effect described arising from an alteration of the tissue microenvironment? Such phenomena as secretion of factors stimulating endogenous stem cells population, or even through an even more general effect, like a decrease in the inflammation response and/or immuno-mediated reaction induced by the grafted cells are possible [Prockop, 2009].

Finally, besides an efficiency issue, a major unanswered question of cell transplantation therapy, concerning adult, embryonic or 


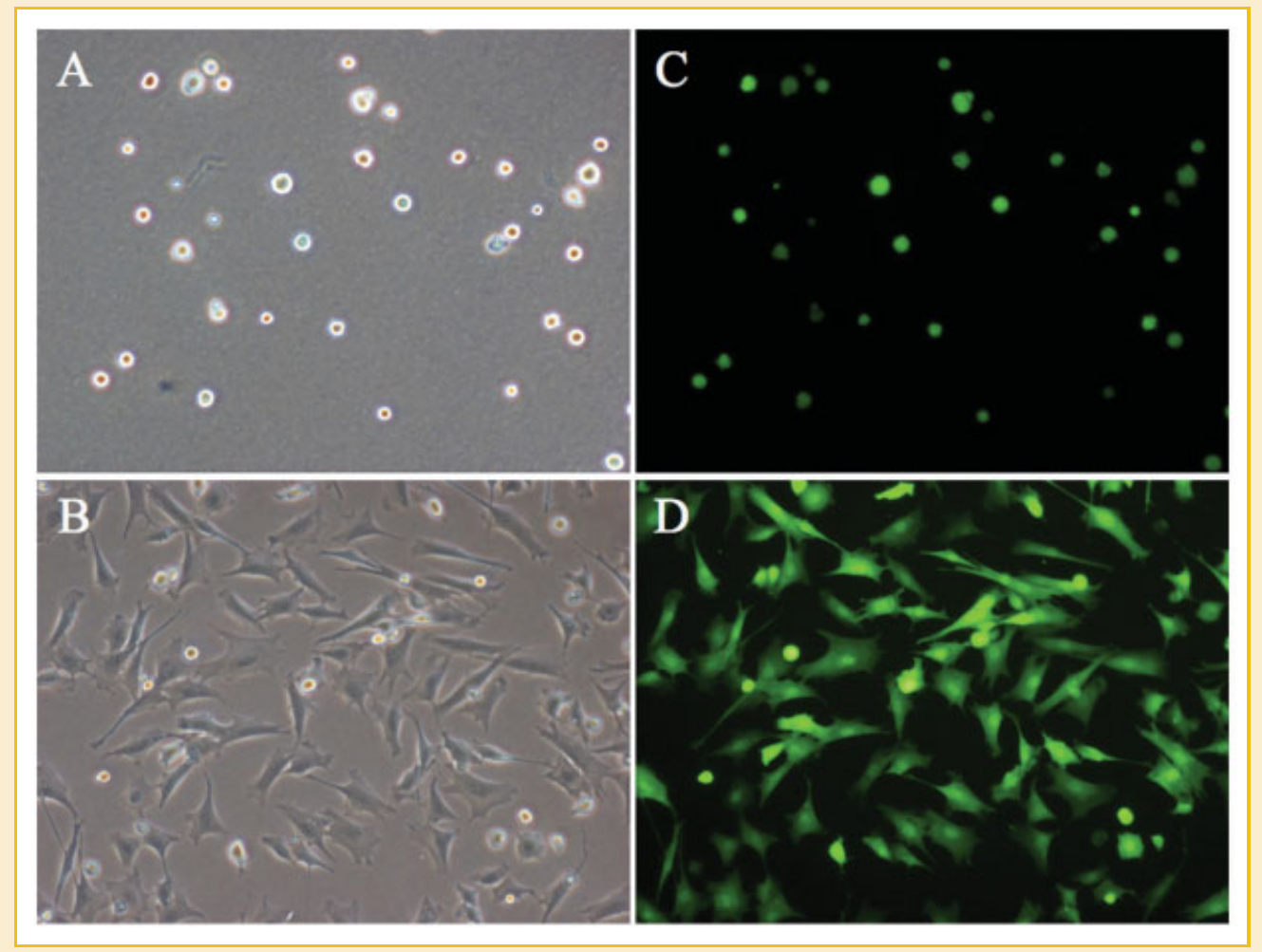

Fig. 5. Sheep MSCs permanently transfected with GFP vector. A and C: cells before attached to growing flask; B and D: cells grown in monolayer; and C and D: GFP positive cells.

even the new pluripotent inducible pluripotent (IP) cells [Takahashi and Yamanaka, 2006; Jeong et al., 2009] is the long-term safety.

Cancer cells and stem cells share many biological properties [Galmozzi et al., 2006; Sell, 2006] and therefore the exclusion of a tumorigenic drift of the transplanted pluripotent cells must be demonstrated beyond any doubt, regardless of the typology of pluripotent cells transplanted (adult, embryonic, and IPs).

To address these concerns, large animals offer unique opportunities for translational and pre-clinical research. Among them, sheep are becoming popular as a model particularly in orthopedic research, for their similarity with humans regarding size, joint structure, and bone cartilage regenerative processes.

However, the immediate hurdle that scientists meet while working on sheep is the lack of cross reactivity with the standard antibodies (human and mice) used for positive immunoselection/ characterization of the mesenchymal cells. In a precedent study, we failed to characterize bone marrow sheep mesenchymal cells using a standard panel of antibodies from various commercial sources, consistent with reports in other studies [McCarty et al., 2009]. The rescue strategy we devised in this study was to use

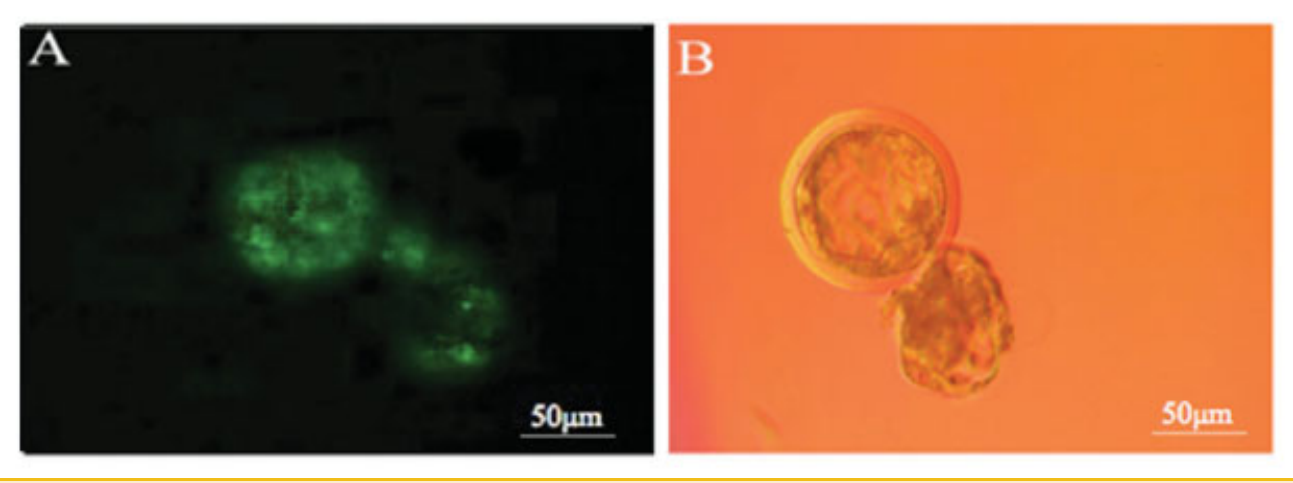

Fig. 6. Sheep 8-day bastocyst after nuclear transfer of GFP transfected MSCs. A: GFP positive blastocyst; and B: blastocyst in contrast phase. 
the classical histochemical approach for assessing the transdifferentiation potential of sheep bone marrow mesenchymal cells. We successfully managed to isolate and expand, through 40 passages, sheep MSCs in culture. On the contrary, in previous reports, cell shapes changed according to the donor animal [Colleoni et al., 2005; McCarty et al., 2009], generating a unique, fibroblast-like phenotype in all cell lines derived from the four donor ewes. This phenotype, along with a normal ploidy, was maintained in all cell lines until passage 40, even when the cell lines were stored frozen.

The in vitro osteogenic, chondrogenic, and adipogenic assays were all successful, with an average of 75\% of the sheep MSCs getting the expected phenotype in all three tests. The presence of a stable marker for the identification of the grafted cells in the context on the transplanted organ is essential, and the GFP has become the standard marker for tracking the cells. Here, we showed that sheep MSCs can be permanently transfected in high proportion and express high levels of the reporter gene. The expression of the GFP was maintained in more than half of the nuclear transfer embryos derived from nuclear transfer of GFP + sheep MSCs, indicating the feasibility to derive multipotent embryonic cell lines to be used in comparative grafting assays. In the other embryos, the expression of the gene was confined to a subset of blastomeres, or not expressed at all, probably as a consequence of alteration of the global pattern of gene expression secondary to nuclear reprogramming.

To conclude, this work represents a proof of principle that sheep mesenchymal cells exhibit morphological and transdifferentiation potential parallel to human bone marrow mesenchymal cells. This work represents a robust contribution to the development of a sheep preclinical model for MCS transplantation in an isogenic context, where adult stem cells (MSCs) and embryonic stem cells might be grafted on the same animal to compare the functional integration and phenotypic/genotypic stability of adult and embryo-derived stem cells.

\section{ACKNOWLEDGMENTS}

This work was supported by the European Research Council (FP7) 2007-2013)/Programme IDEAS Grant No. 210103 to G.E.P. P.L. supported by FP7 EU “NextGen," PRIN 2009 MIUR, and Tercas. Part of this work was supported by EU FP6 Grant No. LSHB-CT-2006037377 (Xenome), EU FP7 Grant No. 223485 (Plurisys) and by Regione Lombardia (Superpig Project) in CG laboratory. We thank Dr Andrea Perota for vector development.

\section{REFERENCES}

Abdallah BM, Kassem M. 2008. Human mesenchymal stem cells: from basic biology to clinical applications. Gen Ther 15:109-116.

Baertschiger RM, Serre-Beinier V, Morel P, Bosco D, Peyrou M, Clément S, Sgroi A, Kaelin A, Buhler LH, Gonelle-Gispert C. 2009. Fibrogenic potential of human multipotent mesenchymal stromal cells in injured liver. PLoS ONE 17:e6657.

Bianco P, Robey PG. 2001. Stem cells in tissue engineering. Nature 414:118121.
Brunetti D, Perota I, Lagutina S, Colleoni R, Duchi F, Calabrese M, Seveso E, Cozzi G, Lazzari F, Lucchini L, Galli C. 2008. Transgene expression of green fluorescent protein and germ line transmission in cloned pigs derived from in vitro transfected adult fibroblasts. Cloning Stem Cells 10:409-419.

Caplan AI. 1991. Mesenchymal stem cells. J Orthop Res 9:641-650.

Caplan AI. 2007. Adult stem cells for tissue engineering versus regenerative medicine. J Cell Physiol 213:341-347.

Colleoni S, Donofrio G, Lagutina I, Duchi R, Galli C, Lazzari G. 2005. Establishment, differentiation, electroporation, viral transduction, and nuclear transfer of bovine and porcine mesenchymal stem cells. Cloning Stem Cells 7:154-166.

Friedenstein AJ, Chailakhyan RK, Gerasimov UV. 1987. Bone marrow osteogenic stem cells: in vitro cultivation and transplantation in diffusion chambers. Cell Tissue Kinet 203:263-272.

Galmozzi E, Facchetti F, La Porta CA. 2006. Cancer stem cells and therapeutic perspectives. Curr Med Chem 13:603-607.

Howlett CR, Cavé J, Williamson M, Farmer J, Ali SY, Bab I, Owen ME. 1986. Mineralization in vitro cultures of rabbit marrow stromal cells. Clin Orthop Relat Res 213:251-263.

Jeong BK, Sebastiano V, Wu G, Araúzo-Bravo PS, Gentile L, Ko K, Ruau D, Ehrich M, Van den Boom E, Meyer J, Hübner K, Bernemann C, Ortmeier C, Zenke M, Fleischmann BK, Zaehres H, Schöler HR. 2009. Oct4-induced pluripotency in adult neural stem cells. Cell 136:411-419.

Johnson A, Dorshkind K. 1986. Stromal cells in myeloidlymphoid long-term bone marrow cultures can support multiple hemopoietic lineages modulate their production of hemopoietic growth factors. Blood 68:1348-1354.

Kadiyala S, Young RG, Thiede MA, Bruder SP. 1997. Culture expanded canine mesenchymal stem cells possess osteochondrogenic potential in vivo and in vitro. Cell Transplant 6:125-134.

Kadouchi I, Sakamoto K, Tangjiao L, Murakami T, Kobayashi E, Hoshino Y, Yamaguchi A. 2009. Latexin is involved in bone morphogenetic protein-2induced chondrocyte differentiation. Biochem Biophys Res Commun 378: 600-604.

Kawaguchi J. 2006. Embryonic stem cell protocols. Volume 2: differentiation models. In: Turksen K, editors. 2nd edition. Humana Press Inc. 144 p. Ottawa Health Research Institute, Ottawa Ontario Canada, Series: Methods in Molecular Biology, Volume No. 330.

Krebsbach PH, Mankani MH, Satomura K, Kuznetsov SA, Robey PG. 1998. Repair of craniotomy defects using bone marrow stromal cells. Transplantation 27:1272-1278.

Kuznetsov SA, Krebsbach PH, Satomura K, Kerr J, Riminucci M, Benayahu D, Robey PG. 1997. Single-colony derived strains of human marrow stromal fibroblasts form bone after transplantation in vivo. J Bone Miner Res 9:13351347.

Lublin FD, Knobler RL, Doherty PC. 1989. Relapsing experimental allergic encephalomyelitis in radiation bone marrow chimars between high and low susceptible strains of mice. Clin Exp Immunol 66:491-496.

Martin PJ, Antin JH, Weisdorf DJ, Paton V, Horowitz MM. 2002. Reporting of adverse event data in hematopoietic stem cell transplantation clinical trials involving investigational new drugs or devices: a report from the William Guy Forbeck Foundation 2001 focus meeting on clinical trials in hematopoietic stem cell transplantation Biol Blood Marrow Transplant 8:295302.

McCarty RC, Gronthos S, Zannettino AC, Foster BK, Xian CJ. 2009. Characterisation and developmental potential of ovine bone morrow derived mesenchymal stem cells. Cell Physiol 219:324-333.

Niwa H, Yamamua K, Miyazaki J. 1991. Efficient selection for high-expression transfectants with a novel eukaryotic vector. Gene 108:193-199.

Phinney DG, Prockop DJ. 2007. Concise review: mesenchymal stem/ multipotent stromal cells: the state of transdifferentiation modes of tissue repair-current views. Stem Cells 25:2896-2902. 
Pittenger MF, Mackay AM, Beck SC, Jaiswal RK, Douglas R, Mosca JD, Moorman MA, Simonetti DW, Craig S, Marshak DR. 1999. Multilineage potential of adult human mesenchymal stem cells. Science 284:143147.

Pittenger MF, Mosca JD, McIntosh KR. 2000. Human mesenchymal stem cells: progenitor cells for cartilage, bone, fat and stroma. Curr Top Microbiol Immunol 251:3-11.

Pittenger MF. Mesenchymal stem cells from adult bone marrow. 2008. Methods Mol Biol 449:27-44.

Ponticiello MS, Schinagl RM, Kadiyala S, Barry FP. 2000. Gelatin-based resorbable sponge as a carrier matrix for human mesenchymal stem cells in cartilage regeneration therapy. J Biomed Mater Res 52(2):246-255.

Prockop DJ. 2009. Repair of tissues by adult stem/progenitor cells (MSCs): controversies, myths, and changing paradigms. Mol Ther 17:939-946.

Procop DJ. 1997. Marrow stromal cells as stem cells for nonhematopoietic tissues. Science 276:71-74.

Ptak G, Loi P, Dattena M, Tishner M, Cappai P. 1999. Offspring from one month old lambs: studies on the developmental capability of prepubertal oocytes. Biol Reprod 61:1568-1574.

Ptak G, Clinton M, Tischner M, Barboni B, Mattioli M, Loi P. 2002. Improving delivery and offspring viability of in vitro-production and cloned sheep embryos. Biol Reprod 67:1719-1725.

Quarto R, Mastrogiacomo M, Cancedda R, Kutepov SM, Mukhachev V, Lavroukov A, Kon Marcacci E. 2001. Repair of large bone defects with the use of autolegous bone marrow stromal cells. N Engl J Med 344:385-386.
Quevedo HC, Hatzistergos KE, Oskouei BN, Feigenbaum GS, Rodriguez JE, Valdes D, Pattany PM, Zambrano JP, Hu Q, McNiece I, Heldman AW, Hare JM. 2009. Allogeneic mesenchymal stem cells restore cardiac function in chronic ischemic cardiomyopathy via trilineage differentiating capacity. Proc Natl Acad Sci USA 106:14022-14027.

Ringe J, Kaps C, Schmitt B, Büscher K, Bartel J, Smolian H, Schultz 0, Burmester GR, Häupl T, Sittinger M. 2002. Porcine mesenchymal stem cells. Induction of distinct mesenchymal cell lineages. Cell Tissue Res 307:321327.

Sell S. 2006. Cancer stem cells and differentiation. Therapy Tumour Biol 27:59-70.

Stief A, Winter DM, Stratling WH, Sippel AE. 1989. A nuclear DNA attachment element mediates elevated and position-independent gene activity. Nature 341:343-345.

Takahashi K, Yamanaka S. 2006. Induction of pluripotent stem cells from mouse embryonic and adult fibroblast cultures by defined factors. Cell 126:663-676.

Terada N, Hamazaki T, Oka M, Hoki M, Mastalerz DM, Nakano Y, Meyer EM, Morel L, Petersen BE, Scott EW. 2002. Bone marrow cells adopt the phenotype of other cells by spontaneous cell fusion. Nature 414:542-545.

Toma C, Pittenger MF, Cahill KS, Byrne BJ, Kessler PD. 2002. Human mesenchymal stem cells differentiate to a cardiomyocyte phenotype in the adult murine heart. Circulation 105:93-98.

Ying QL, Nichols J, Evans EP, Smith AG. 2002. Changing potency by spontaneous fusion. Nature 416:545-548. 